\title{
CZECH MANAGERIAL COMPENSATIONS: WHY DOES IT PAY OFF TO CLIMB THE CORPORATE LADDER?
}

\section{Teodora Paligorova}
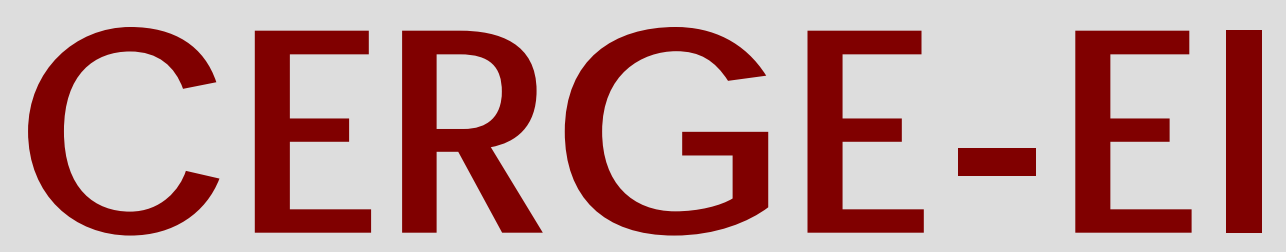

Charles University Centerfor Ec onomic Research and Graduate Educ ation Academy of Sciences of the Czech Republic Ec onomic Institute 


\section{Working Paper Series 262 (ISSN 1211-3298)}

\section{Czech Managerial Compensations: Why Does It Pay Off to Climb the Corporate Ladder?}

Teodora Paligorova

CERGE-EI

Prague, June 2005 
ISBN 80-7343-054-1 (Univerzita Karlova v Praze, CERGE)

ISBN 80-7344-043-1 (Národohospodářský ústav AV ČR, Praha) 


\title{
Czech Managerial Compensations: Why Does It Pay Off to Climb the Corporate Ladder? ${ }^{1}$
}

\author{
Teodora Paligorova ${ }^{2}$
}

CERGE-EI

\begin{abstract}
This paper uses matched employer-employee data for the Czech Republic to study the structure of managerial compensation. The evidence supports two key predictions from tournament theory. First, the managerial pay differential between organizational levels is non-decreasing as one goes up the corporate ladder. I document a particularly large increment of the pay differential at the top of a firm's hierarchy. Second, the winner's prize in the tournament increases with the number of competitors for the position of the top managers.
\end{abstract}

\begin{abstract}
Abstrakt
Tento článek využívá odpovídající data zaměstnanců a zaměstnavatelů z České republiky ke studiu struktury manažerských odměn. Tato evidence podporuje dva klíčové předpoklady teorie turnaje. Zaprvé, rozdíl v manažerských odměnách mezi organizačními stupni se nezmenšuje se vzestupem na podnikovém žebřričku. Dokládám obzvláště velký nárůst rozdílu v odměnách na vrcholu podnikové hierarchie. Zadruhé, cena pro vítěze v turnaji vrcholových manažerů se zvyšuje s počtem uchazečů o pozici.
\end{abstract}

Keywords: Czech Republic, tournament models, matched employer-employee data JEL classifcation: J31; J41

\footnotetext{
${ }^{1}$ I would like to thank $\cdot$ Stepan Jurajda for providing remote access to the data and for helpful suggestions and comments throughout the writing of the paper.

2 CERGE-EI is a joint workplace of the Center for Economic Research and Graduate Education, Charles University, and the Economics Institute of the Academy of Sciences of the Czech Republic. Address: CERGE-EI, P.O.Box 882, Politickych veznu 7, Prague, Czech Republic. E-mail: teodora.paligorova@cerge-ei.cz.
} 


\section{Introduction}

In recent years, economists have devoted considerable attention to the normative properties of different compensation schemes and especially to the incentives they provide. Among the schemes discussed, tournaments have drawn much attention. They predict that salaries mainly increase throughout a firm's hierarchial levels due to incentive reasons, rather than because of heterogeneity in human capital characteristics (Lazear and Rosen, 1981; Green and Stokey, 1983; Rosen, 1986). Tournament models are of more than academic interest since they provide an explanation for skewed pay structures and hence, the high levels of CEO pay compared to other occupations' compensation. ${ }^{1}$ Most of the empirical evidence comes from U.S. and West European data and shows that firms in these countries indeed employ tournament-like incentives as part of their corporate governance. ${ }^{2}$ This paper studies the same issue in one post-communist country: the Czech Republic.

Since in the last decade the majority of Czech firms have been privatized, the new owners have faced corporate governance challenges to find compensation schemes stimulating their managers to act in the companies' best interest. ${ }^{3}$ During communism managers were not motivated to increase firm productivity, but rather they "faced a mix of monetary and career-based incentives, which were a function of plan fulfilment, enterprise performance and political loyalty" (Djankov and Murrell, 2002, p.7). There is research on transition corporate governance (Claessens et al., 1999; Frydman et al., 1999), however, there is no evidence on relative compensation packages in firms in transition countries. The lack of evidence and the unique transition corporate governance mechanisms in comparison with the U.S. and West European countries call for an analysis of the usage of tournament managerial compensation schemes as incentives for higher productivity.

This paper contributes to the understanding of hierarchical organizations by providing

\footnotetext{
${ }^{1}$ Jensen and Murphy (1990), Crystal (1992), and Abowd and Bognanno (1995).

${ }^{2}$ Main et al. (1993); Lambert et al. (1993); Gibbs (1995); Chan (1996); Eriksson (1999); Bognanno (2001).

${ }^{3}$ Aghion et al. (1994) and Shleifer et al. (1997) agree that the incentive systems of managers are crucially important for transition reforms to be successful.
} 
empirical evidence on the distribution of managerial salaries and their incentive effect across the corporate ladder in a sample of Czech firms. So far, the empirical literature on Czech firms has primarily studied their ownership structure and performance (Estrin, 2002) but not the managerial relative reward packages. This paper will be the first to examine whether Czech firms implement tournament-based wage policies to elicit a higher effort response from their managers and to explore the relationship between the compensation of upper- and middle level managers.

I focus on the following testable predictions of tournaments. The first major hypothesis is that the function describing the relationship between executive compensation and organizational level is convex. In addition, I ask whether the difference in compensation levels for the top manager and his competitors is "especially" large relative to the changes in compensation levels observed at other points in the firm hierarchy. The second major hypothesis is that the number of tournament participants increases the prize, i.e the difference between top manager and competitors' compensation.

The paper is organized as follows. The next section provides a brief discussion of the existing theoretical and empirical literature on relative compensations. In section 3 , I describe the data set and the analysis-ready sample; section 4 describes the empirical specification, while section 5 reviews the results. Section 6 concludes.

\section{Tournament Compensation Schemes: Literature Review}

Lazear and Rosen (1981) model internal compensation as sequential elimination tournaments, in which managers compete against one another in a related series of tournaments. Tournament models could be regarded as a reduced form of agency models, ${ }^{4}$ meaning that the managers work for a principal who has committed to a compensation contract, but it does not provide a complete statement of the principal's problem.

It is assumed that the principal wants to place high-performing agents in upper-level

\footnotetext{
${ }^{4} \mathrm{An}$ alternative model for understanding the structure of compensations is the agency model (Holmstrom, 1979; Grossman and Hart, 1983), in which the compensation contracts have to realign the interests of the risk-averse self-interested manager to those of the shareholders. For that purpose, the optimal contract the principal offers is an increasing function of performance.
} 
managerial positions because they choose the strategy of the firm and can potentially affect their subordinates. Agents compete against one another at the $n$-th organizational level. Considering their relative performances, high-performance agents are promoted to the next organizational level and receive a prize that is the difference of compensations between the two adjacent levels. Since only relatively high-performing agents advance up the corporate ladder, sequential elimination tournaments enable firms to identify managerial talent and optimally match agents to organizational positions.

The theory implies that the salary of a corporations' top executives may exceed their marginal product and yet be efficient because it will create adequate incentives for the employees lower on the corporate ladder to exert effort in order to be promoted to a better-paid position. Lazear (1998) implies that the managers who move up the corporate ladder do so by being better than their peers, not necessarily by being good. Hence, the message behind tournament theory is that it may be necessary to design large salary differences among the organizational hierarchies of a firm, where the participants compete for a fixed prize and are rewarded for their relative performance. ${ }^{5}$

Tournament theory suggests several testable implications concerning the shape of the internal compensation structure across organizational levels that are explored in this paper. First, greater prizes lead to more effort. This hypothesis suggests that the function describing managerial compensations is convex with respect to the levels of corporate hierarchies. Second, the difference in compensation for the top manager relative to the next lower position in the organizational hierarchy should be "extraordinarily" large relative to changes in compensations at other points in the hierarchy. Third, more competitors increases the prize for becoming top manager.

Prior studies have found support for the convexity of internal compensation structure. ${ }^{6}$ Using U.S. data for managers, O’Reilly et al. (1988), Leonard (1990), Main et al. (1993), and Lambert et al. (1993) have shown that differences between the hierarchical

\footnotetext{
${ }^{5}$ See Ehenberg and Bognanno (1990); Cappelli (1991); Prendergast (1999); Bloom (1999).

${ }^{6}$ This prediction is verified in several studies of sports (Ehrenberg and Bognanno, 1990; Becker and Huselid, 1992).
} 
levels are non-decreasing, and are therefore consistent with the theory. ${ }^{7}$ For a sample of British firms, Conyon et al. (2001) find a convex executive compensation, similarly to Eriksson (1999), who studies a sample of Danish firms. Heyman (2002), however, does not find a convex pay structure for Swedish managers.

The "extraordinarily" large increment of the prize at the top of the hierarchy is confirmed by Leonard (1990), Main et al. (1993), and Lambert et al. (1993) using U.S. data, and Heyman (2002) using Swedish data. Eriksson (1999) does not find evidence for a large increase of the prize at the top of the corporate ladder with his Danish sample.

The last prediction that the tournament prize is increasing with the number of competitors is derived by McLaughlin (1988). Since the marginal increment of effort decreases with a lower probability of winning (larger number of contestants), in order to provide an incentive for higher effort, the prize spread should increase. Each tournament participant implicitly gives up some of their expected salary associated with their marginal product or performance. This excess becomes part of the tournament prize. Empirical support in favor of this proposition is provided by Main et al. (1993) and Bognanno (2001) for a sample of U.S. corporations. Conyon et al. (2001) and Eriksson (1999) also illustrate this relationship using European data.

\section{Data Description and Basic Statistics}

This study uses data from a quarterly national employer survey, called the Information System on Average Earnings (ISAE). ${ }^{8}$ from the first quarter of 2001. It contains hourly wages, gender, education, age, a detailed occupational classification, the number of employees and the ownership type for each sampled firm. The wage records are drawn directly from the firms' personnel database and the definition of hourly wage is detailed and fully consistent across firms; it includes total cash compensation and bonuses and other special payment divided by total hours worked for that quarter. ${ }^{9}$ Having available such a complete measure of compensation makes the data appropriate for a study like

\footnotetext{
${ }^{7}$ Baker, Gibbs and Holmstrom (1994) also confirm this result with data on a single firm.

${ }^{8}$ The survey is conducted for the Czech Ministry of Labor and Social Affairs.

${ }^{9}$ Bonuses and additional payments are spread evenly over the whole year.
} 
this that asks whether firms provide tournament-based incentive schemes for their managers. However, in the data there is no information about stock and/or stocks that top managers are often provided. ${ }^{10}$ The data consist of 32,900 chief executives, directors, and production and specialist managers in 2,296 firms, which are classified according to the single largest owner into private, foreign, state, cooperative and mixed (firms without a majority owner). ${ }^{11}$

Unfortunately, in the data set some firms have missing manager records. I investigate if the lack of manager records is random across firms and discover that the missing records are randomly distributed across ownership type and firm size. Specifically, a logit model is estimated, where the left-hand side variable is equal to one if the firm has a missing manager and zero otherwise. ${ }^{12}$ The right-hand side variables include the type of ownership and size measured with the number of employees. The results suggest that the private, foreign and cooperative firms are equally likely not to report their mangers; both middle-size firms (from 251 up to 500 employees) and large-size firms (above 500 employees) do not differ from small firms (from 50 up to 250 employees) in this respect.

Table 1 presents the initial sample and the missing observations. It shows that out

\footnotetext{
${ }^{10}$ Murphy(1999) discusses the components of the managerial compensations. In the last decade the significance of stock and stock options as a part of the total compensation package is increasing. However, in transition economies their importance is not yet that high.

${ }^{11}$ The managerial classification in the ISAE data set corresponds closely to major group one of ISCO$88(\mathrm{COM})$. It consists of three groups of managers: chief executives and/or directors, production managers and specialist managers. The chief executives and directors are the top level managers. Some firms report more than one top manager, which suggests that I cannot identify exactly who the chief executive officer is. However, this is not crucial for this study because the tournament compensations require definition of hierarchy structure, not separate positions. Obviously, the group of chief executives and directors, which I name "Top Managers", occupies a higher position than production and specialist managers. Production managers are classified according to the operation field like agriculture, manufacturing, construction, wholesale, etc. Specialist managers are divided into finance and administrative, personnel, sales and marketing, distribution, and computer managers. In this study, I combine both production and specialist managers unless otherwise specified and name them "Middle Managers". See International Labor Office (1990), ISCO-88 (COM): International Standard Classification of Occupations for details.

${ }^{12}$ The detailed results are available from the author upon request.
} 
of 1,721 firms, 721 do not report their top managers, and 230 do not report their middle managers, classified as production and specialist managers.

Table 1: Sample Size

\begin{tabular}{lcc}
\hline & $\begin{array}{c}\text { Number of } \\
\text { Individuals }\end{array}$ & $\begin{array}{c}\text { Number of } \\
\text { Firms }\end{array}$ \\
\hline Top Managers & 1613 & 1721 \\
Top Managers Not Reported & & 721 \\
Middle Managers & 29903 & 1721 \\
Middle Managers Not Reported & & $230^{a}$ \\
Wage Grid & & 697 \\
Wage Grid Not Reported & 15521 & 1024 \\
Analysis Sample & & 345 \\
\hline Notes: $^{a}$ The number of firms that simultaneously report all types $^{b}$ & 8905 & of managers is $726 .{ }^{b}$ Includes total number of managers. ${ }^{c}$ Con- \\
sists of top and middle managers with wage grid reported.
\end{tabular}

Some of the firms also report a wage grid. The wage-grid classification was originally inherited from the centrally planned regime where every worker, depending on their education, experience, occupation and industry was assigned a wage grid level. This policy did not leave room for managerial discretion, kept the dispersion of wages between grids low and purposefully maintained "equality" between skilled and unskilled workers (Munich et al., 2005). Since the collapse of the communist regime in 1989, however, salaries are determined by market forces (Svejnar, 1999), but some firms use a potentially modified wage-grid system to suit individual firm-specific wage policies. An important question is whether the grid level continues to reflect years of experience and education level or whether it is now used to express levels of hierarchy within firms. To distinguish between these two explanations, I perform a regression analysis of the wage grid level of managers on their age and education. This analysis shows that these variables explain only $8 \%$ of the total variation in the grid class. Therefore, I argue that the present wage grid differs by structure and purpose from the old one, inherited from the communist regime. In the subsequent analysis, I apply this grid classification to detect hierarchy levels for managers and to study whether their compensation is related to the hierarchy in a way tournament theory predicts.

Since the wage grid is not available for all of the companies, I perform a selectivity 
analysis similar to that carried out for the incidence of missing managers. The results show that private and foreign firms are equally likely not to report a manager wage grid while state firms are more likely to assign a wage grid to their managers. Since the proportion of state firms in the whole sample is less than $10 \%$, I ignore the impact of this tendency on the final results.

Firms do not use the same grid scale across managers. For example, the grid level for top managers varies from nine to thirteen. Since I am not concerned with the grid number itself, but with the ranking, I order the top managers grid level as the maximum level (the data shows that indeed the firms assign their top managers to the maximum level within a company); the next lower level is assigned to middle managers that are in the same grid as the top managers; the following lower levels are managers who are attributed to one level below the maximum grid up to managers at six grid levels below the maximum level (this is the lowest obtained managerial rank). Therefore, I construct a hierarchy structure with six grid levels ranked beneath the maximum hierarchy level in a firm.

Thus, the analysis-ready sample contains 345 firms that report both their managers and a wage grid. The missing data on managers and wage grids are the main drawbacks of the current analysis because the representativeness of the sample is not guaranteed. ${ }^{13}$ Table A1 in the Appendix provides descriptive statistics across seven hierarchy levels. As expected, the average hourly wage increases with the grid class and the proportion of people with college education is higher in the upper hierarchy levels, while the proportion of women is larger in the lower grid classes.

\section{Empirical Specification}

I estimate compensation equations, expressed as a function of individual characteristics (age, gender, education level), firm characteristics (type of ownership, company size),

\footnotetext{
${ }^{13}$ No alternative definition of hierarchy is available in the data; therefore, I can not check the sensitivity of the results to the way I determine the hierarchy.
} 
and positions in the company hierarchy. The basic regression equation is as follows:

$$
\begin{aligned}
W_{i}= & \alpha_{0}+\beta_{1} \text { Age }_{i}+\beta_{2} \text { Age }_{i}^{2}+\beta_{3} \text { Gender }_{i}+\sum_{j=1}^{3} \delta_{j} \text { Education }_{j i}+ \\
& \sum_{m=1}^{4} \gamma_{m} \text { Ownership }_{m i}+\sum_{k=1}^{2} \theta_{k} \text { Size }_{k i}+\sum_{l=1}^{7} \lambda_{l} \text { JobLevel }_{l i}+\epsilon_{i}
\end{aligned}
$$

where $W_{i}$ is the logarithm of quarterly average hourly compensation for manager $i$;

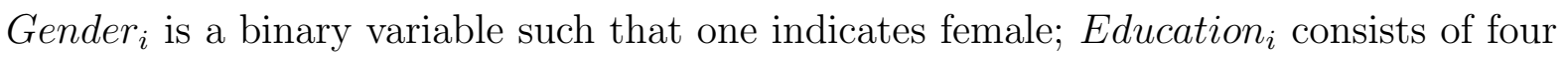
dummies for primary, apprenticeship secondary and university education; Owner ship $p_{i}$ is a set of firm ownership dummies (foreign, private, state, mixed, cooperative); $S_{i z e_{i}}$ is a set of dummy variables indicating whether a manager works at small (from 50 to 250 employees), middle-sized (from 251 to 500 employees) or large company (more than 500 employees). Finally, Level $_{i}$ is a set of job-level dummy variables. The highest level in the hierarchy belongs to the top managers with maximum wage grid level, then managers in the same maximum grid level are ranked, followed by managers classified into six grid levels down the corporate ladder.

The first testable hypothesis suggests that the relationship between the compensation and hierarchy is convex. Using regression parameters ${ }^{14} \mathrm{I}$ test the zero hypothesis $\lambda_{2}=0$; $\lambda_{3}-\lambda_{2}=\lambda_{2} ; \lambda_{4}-\lambda_{3}=\lambda_{3}-\lambda_{2} ; \lambda_{5}-\lambda_{4}=\lambda_{4}-\lambda_{3} ; \lambda_{6}-\lambda_{5}=\lambda_{5}-\lambda_{4} ; \lambda_{7}-\lambda_{6}=\lambda_{6}-\lambda_{5} ;$ $\lambda_{8}-\lambda_{7}=\lambda_{7}-\lambda_{6}$;. The term convex is used to refer to a function in which compensation differences across adjacent hierarchy levels are nondecreasing and concave to refer to a function in which the differences are non-decreasing.

Managerial compensation data from many firms form a clustered sample, where each firm is a cluster (group). The error term of the regression equation likely consists of both a common cluster term and an idiosyncratic term. For example, it might turn out that managers in certain firms receive higher compensations because of an unobservable firm specific factor and/or because of an individual unobservable characteristic. Moulton (1990) demonstrated how an explanatory variable that was completely unrelated to the outcome of interest might be mistakenly estimated to have a significant relation if the

\footnotetext{
${ }^{14}$ Let us denote the estimates for the job-level dummies: top manager maximum grid level $-\lambda_{8}$; manager in the same wage grid level $-\lambda_{7}$; manager in one grid class below the top manager - $\lambda_{6}$; manager two levels below the top managers $-\lambda_{5}$, followed by $\lambda_{4}, \lambda_{3}, \lambda_{2}$ and $\lambda_{1}$ (reference group).
} 
values of this variable were common across many individuals in the same group.

If the explanatory variables are correlated with the common cluster error term, then firm fixed-effect estimation is preferred (Wooldridge, 2002). If the common cluster error term is uncorrelated with the explanatory variables, then least squares estimation can be used but correcting the standard errors for the group effect. That is why I apply two estimation methods: firms fixed effect and ordinary least squares with adjusted variancecovariance matrix.

\section{Results}

Prior to running the regressions, I examined the structure of the compensation data. The proportional pay differences between adjacent levels, presented in Table 2, show that as one moves up the corporate ladder the pay differences are non-decreasing. The structure of the managerial pay is consistent with the tournament theory pay that implies growing increments up the hierarchy. ${ }^{15}$ This pattern gives grounds to continue the analysis with controlling for firm and individual characteristics in the regression framework.

Table 2: Payment Increase by Levels in Corporate Hierarchy

\begin{tabular}{lcccc}
\hline Job Level & $\begin{array}{c}\text { Number of } \\
\text { Managers }\end{array}$ & $\begin{array}{c}\text { Number of } \\
\text { Firms }\end{array}$ & $\begin{array}{c}\text { Pay } \\
\text { Differential }^{a}\end{array}$ & $\begin{array}{c}\text { 95\% Confidence } \\
\text { Interval }\end{array}$ \\
\hline Top managers & 585 & 345 & 464.92 & $(433.75,469.19)$ \\
Level 7 & 4593 & 277 & 255.57 & $(251.36,259.78)$ \\
Level 6 & 738 & 111 & 197.59 & $(191.60,203.58)$ \\
Level 5 & 636 & 99 & 170.78 & $(165.93,175.63)$ \\
Level 4 & 906 & 92 & 148.92 & $(144.63,153.22)$ \\
Level 3 & 641 & 85 & 118.43 & $(115.07,121.79)$ \\
Level 2 & 364 & 51 & 96.01 & $(92.03,99.99)$ \\
Level 1 & 788 & 56 & 88.23 & $(86.60,89.86)$ \\
\hline \multicolumn{2}{c}{ Note: ${ }^{a}$ Significantly different at $5 \%}$. & &
\end{tabular}

I estimate both firm fixed effect and OLS regressions. The results for the hierarchy

\footnotetext{
${ }^{15}$ Similarly to Eriksson (1999), I find that the increase of salary increase is smaller than at the second level. This "odd" feature could be due to individual characteristics that are considered in the regression analysis.
} 
dummies are presented in Table A2 in the Appendix. The OLS estimates suggest that beginning from the lowest grid the pay increases by $0.12,0.15,0.31,0.39,0.45,0.65$ and $1.16 \log$ scale points. After controlling for firms fixed effect, the increase per job level is $0.16,0.23,0.33,0.45,0.53,0.76$ and $1.30 \mathrm{log}$ scale points starting from the lowest level. The results from the firm-fixed effect regression are slightly higher than in the OLS regression. This difference is not important for the level of the analysis focusing on the increasing growth of the reward.

I check whether the results are driven mainly by firms with a large number of managers by splitting the sample into two subsamples. The first consists of 260 firms with less than 26 middle managers and 2,695 observations (the frequency of firms with more than 26 top and middle managers reduces to one) and the second contains 66 firms and 6,157 observations. I run OLS regressions with standard error correction and conclude that the results are driven mainly by the larger subsample of firms. Thus, we can regard the results as robust to firms with a substantial number of managers.

In order to test whether the pay structure is convex, the conditions stated in the empirical analysis should be tested. The results based on both OLS and firm fixed-effect estimation are presented in Table 3. To conclude that convex pay structure is present, it is necessary that the inter-grid spread between two adjacent levels should be non-decreasing to the inter-grid spread between subsequent lower levels. We observe that the inter level spread is indeed positive and statistically significant between the top manager and the seventh level, compared with the spread for the seventh level manager and level six 0.30 (OLS) and 0.31 (firm fixed-effect). In the case of negative inter level difference, the results are not significant, which could imply that the spread does not change from level five until it reaches level zero or the top manager position on the hierarchy ladder. I find out that there is no difference between OLS and firm fixed-effect estimates, which suggests that the spread difference between adjacent levels is not influenced by any unobserved firm specific factors.

The non-decreasing growth of rewards along the corporate ladder is consistent with other economic theories as well. Any model with increasing returns to talent in hierar- 
Table 3: Testing Convexity Hypotheses

\begin{tabular}{|c|c|c|c|}
\hline & Raw & OLS & Firm \\
\hline & Log-Differential & & \\
\hline \multirow[t]{2}{*}{ Top Managers/Level 7 vs. Level 7/Level 6} & $0.40^{* * *}$ & $0.30^{* * *}$ & $0.31^{* * *}$ \\
\hline & $(0.16)$ & $(0.25)$ & $(0.26)$ \\
\hline \multirow[t]{2}{*}{ Level 7/Level 6 vs. Level 6/Level 5} & $0.24^{* * *}$ & $0.16^{* *}$ & $0.15^{* * *}$ \\
\hline & $(0.07)$ & $(0.14)$ & $(0.13)$ \\
\hline \multirow[t]{2}{*}{ Level 6/Level 5 vs. Level 5/Level 4} & -0.05 & -0.03 & -0.04 \\
\hline & $(0.03)$ & $(0.13)$ & $(0.13)$ \\
\hline \multirow[t]{2}{*}{ Level 5/Level 4 vs. Level 4/Level 3} & $0.05^{* *}$ & -0.08 & $0.02^{*}$ \\
\hline & $(0.02)$ & $(0.14)$ & $(0.14)$ \\
\hline \multirow[t]{2}{*}{ Level 4/Level 3 vs. Level 3/Level 2} & $0.09^{* *}$ & $0.13^{*}$ & 0.03 \\
\hline & $(0.01)$ & $(0.11)$ & $(0.12)$ \\
\hline \multirow[t]{2}{*}{ Level 3/Level 2 vs. Level 2/Level 1} & 0.02 & -0.08 & -0.07 \\
\hline & $(0.01)$ & $(0.09)$ & $(0.09)$ \\
\hline \multirow[t]{2}{*}{ Level 2/Level 1} & $0.20^{* * *}$ & $0.12^{* * *}$ & $0.16^{* * *}$ \\
\hline & $(0.15)$ & $(0.04)$ & $(0.02)$ \\
\hline
\end{tabular}

chical production, for instance through positive externalities on the productivity of subordinates, generates this prediction. Optimal human capital allocation models (Rosen, 1982; Waldman, 1984) explain compensation differences as a function of heterogeneity in ability and talent. Thus, if the firm sorts employees by talent, the people at the top of the hierarchy would be more talented and will have higher marginal productivity. In order to distinguish if the pay difference across levels is due to marginal product or to tournament-like incentive effect, I investigate what part of the explanatory power is due to disparities in human capital characteristics. I find that $35 \%$ of the total explanatory power attributed to levels is due to human capital heterogeneity. ${ }^{16}$ Thus the rest leaves room for incentive effect differences across levels.

\footnotetext{
${ }^{16} \mathrm{I}$ decompose the total sample variance in managerial pay into the parts explained by hierarchical levels, firm-specific effects and human capital variables. First, I study the contribution to the $\mathrm{R}^{2}$ of each set of variables. Second, to evaluate the full contribution of human capital variables, I take into account the explanatory power between hierarchical levels. Ortin-Angel et al. (2002) perform a similar exercise and conclude that $50 \%$ of the variation in compensation is due to differences in human capital endowment throughout hierarchical levels.
} 
The results in Table A2 support the hypothesis of the tournament model that the difference in compensation level between the top managers and the next lower position (Level 7) in the organizational hierarchy is "extraordinarily" large relative to changes in the compensation levels observed at other points in the hierarchy. ${ }^{17}$ I employ the definition for "extraordinarily" large proposed by Lambert et al. (1993) who claim that the spread between the top managers and the next lower level managers has to be greater than the average of inter rank spreads for the rest of the levels. According to tournament theory, the last "prize" is higher since it also includes an additional reward for the lack of further positions after the top manager. This prediction is unique to tournament theory. Therefore, finding support for it provides stronger evidence for identifying tournamentlike incentive schemes in the present sample of Czech firms.

The firm-specific characteristics and firm size are measured with the type of ownership and the number of employees. Consistent with previous research on the Czech Republic, foreign owned firms pay more than private, state, mixed and cooperative firms. One of the limitations of my study is that it does not examine the impact of the hierarchy across types of owners due to data limitations. This analysis could produce important insights into incentive policies for managers employed by different owner types.

Many papers have documented the fact that managerial compensation increases with the size of the firm. ${ }^{18}$ The results offered here confirm the previous evidence that the elasticity of compensation to size is significantly positive, namely $11 \%$ higher for larger firms than smaller ones.

The last prediction of tournament theory is that the increase in the number of potential competitors for the top manager position increases the prize. I measure the prize spread as the difference between the top manager pay and the average salary of the contestants. This measure is also employed by Eriksson (1999), Main et al. (1993) and O'Reilly et al. (1988). Considering the firm hierarchy as captured by the wage grid, I as-

\footnotetext{
${ }^{17}$ The results are available from the author upon request. Two-tailed test is performed and is significant at $p<0.01$

${ }^{18}$ Murphy (1985) shows that this result is robust to the inclusion of performance variables and firm specific effects.
} 
sume that the most plausible competitors for the top manager position are the managers in the same hierarchy level as the top manager, i.e. the competitors are the managers at Level 0 .

The results from the estimation are presented in Table 4. The estimates suggest that after controlling for firm size and ownership type, the greater number of contestants increases the prize spread by $2.8 \%$. The magnitude of this result is similar to Main et al. (1993), Bognanino (2001), and stronger than in Eriksson (1999). It confirms the prediction of the theory that the contestants are provided with larger prizes as the probability to win decreases, thus providing incentives for higher effort. The second column of Table 4 shows additional regression checking the robustness of the result. I interact the type of ownership with the number of competitors to check whether the estimate is the same across firm type. I find that all the interaction terms are insignificant and the coefficient of the number of contestants is $2.3 \%$.

\begin{tabular}{|c|c|c|}
\hline Dependent Variable & \multicolumn{2}{|c|}{ Log-Pay Differential $^{a}$} \\
\hline \multirow[t]{2}{*}{ Constant } & $0.52^{* * *}$ & $0.36^{* * *}$ \\
\hline & $(0.12)$ & $(0.09)$ \\
\hline \multirow[t]{2}{*}{ Number of Contestants } & $0.028^{* * *}$ & $0.023^{* * *}$ \\
\hline & $(0.01)$ & $(0.01)$ \\
\hline Ownership dummies & Yes & Yes \\
\hline Interaction $^{b}$ & No & Yes \\
\hline$R^{2}$ & 0.27 & 0.27 \\
\hline Observations & 276 & 276 \\
\hline \multicolumn{3}{|c|}{ Notes: ${ }^{* * *} p<0.01$; Clustered standard errors in paren } \\
\hline
\end{tabular}

In the present sample, the managers are classified as production and specialist managers. In order to investigate if the estimate of the number of competitors is robust to the type of manager, I perform a separate analysis. The estimates for the number of competitors are a $2.6 \%$ prize for production managers and $2.3 \%$ for specialist managers. Consequently, they do not differ statistically. This might suggest that both groups are 
treated equally with respect to the provision of incentive to compete for a top manager position. In the context of the Czech managerial labor market where in the past "the typical manger was a production engineer and not a businessman" (Djankov and Murrell, 2002), this result suggests that neither the production managers nor the specialist managers are likely to be more motivated to become top managers. This is contrary to the practice during the communist regime, where production managers were treated more preferably than specialist managers.

\section{Concluding Remarks}

The literature on corporate managers focuses primarily on their incentives to improve the performance of firms. In transition economies, two theories have been extensively explored. First, researchers ask to what extent managerial ownership leads to optimal profit. Second, the effect of managerial turnover on firm profit is also extensively studied.

In contrast, this paper is the first to investigate tournament style aspects of Czech managerial compensations. The tournament theory approach assumes that firms motivate managers by running competitions for promotions, thereby paying them according to the performance of peers. In such a way, the incentives depend on the corporate environment, contrary to the traditional individualistic schemes that ignore the impact of peers.

I explore empirically two main testable predictions of tournament theory using a large set of Czech data. First, I find that there is a convex relationship between pay and job level. Further, consistent with theory predictions, I find an "extraordinarily" large compensation increase at the top of the firm hierarchy. Next, the prediction of a positive relationship between the number of participants and the prize of the tournament is also confirmed. Therefore, I find evidence that 15 years into market reforms Czech firms do implement relative compensation schemes.

One important limitation of the data is that many firms from the initial sample do not report the wage grid class, which is used here to capture within-firm hierarchy, hence challenging the representativeness of the analyzed sample. Another limitation is that I can not check the sensitivity of the results to the hierarchical job-level definition adopted. 
Finally, the data do not allow me to study separately the foreign, private, state owned, mixed and cooperative firms.

An avenue for future research is to study how the tournament-like incentives impact company performance. Previous literature shows that they can influence the profits positively or negatively depending on the corporate team dependance. Hence, these incentives may turn out to be destructive for firms that depend on team cooperation and successful for firms that need competition among peers to improve performance. Therefore, further analysis of corporate team dependence will shed light on the type of incentive devices that optimize firm profit. 


\section{References}

[1] Abowd, J., and M. Bognanno (1995) "International Differences in Executive and Managerial Compensation," in R. Freeman, and L. Katz, ed., Differences and Changes in Wage Structures, Chicago: The University of Chicago Press, 67-103.

[2] Aghion, P., O. Blanchard, and S. Burgess (1994) "The Behavior of State Firms in Eastern Europe Privatization", European Economic Review, 38, 1327-1349.

[3] Baker, G., Michael Gibbs and Bengt Holmstrom (1994) "The Internal Economics of the Firm: Evidence from Personnel Data", Quarterly Journal of Economics, 109, 881-919.

[4] Becker, B. and M. Huselid (1992) "The Incentive Effects of Tournamnet Compensation Systems", Administrative Science Quaterly, 37, 336-350.

[5] Bloom M. (1999) "The Performance Effect of Dispersion on Individuals and Organizations", Academy of Management Journal, 42, 24-40.

[6] Bognanno, Michael L. (2001) "Corporate Tournaments", Journal of Labor Economics, 19, 290-315.

[7] Cappelli P. Cascio (1991) "Why some Jobs Command Wage Premiums: a Test of Career Tournaments and Internal Labor Market Hypotheses", Academy of Management Journal, 34, 848-868.

[8] Chan, William (1996) "External Recruitment versus Internal Promotion", Journal of Labor Economics, 14, 555-70.

[9] Claessens, Stijn, and Simeon Djankov (1999) "Ownership Concentration and Corporate Performance in the Czech Republic" Journal of Comparative Economics, 27, 498- 513.

[10] Conyon M., S. Peck, G.V.Sadler (2001) "Corporate Tournaments and Executive Compensation: Evidence from the U.K", Strategic Management Journal, 22, 805815. 
[11] Crystal, G. (1991) "In Search of Excess: The Overcompensation of American Executives", W. W. Norton \& Company: New York.

[12] Djankov, S. and P. Murrell (2002) "Enterprise Restructuring in Transition: A Quantitative Survey", Journal of Economic Perspectives, 40, 739-792.

[13] Ehrenberg, Ronald, and M. Bognanno (1990) "The Incentive Effects of Tournaments Revised: Evidence from the European PGA Tour", Industrial and Labor relations Review, 43, 74-88.

[14] Estrin, S. (2002) "Compensation and Corporate Governance in Transition", Journal of Economic Perspectives, 16, 101-124.

[15] Frydman, Roman, Cheryl W. Gray, Marek Hessel, and Andrej Rapaczynski (1999) "When Does Privatization Work? The Impact of Private Ownership on Corporate Performance in the Transition Economies", Quarterly Journal of Economics, 114, 1153-91.

[16] Gibbs Michael (1995) "Incentive Compensation in a Corporate Hierarchy", Journal of Accounting and Economics, 19, 247-77.

[17] Grossman, S. and O. Hart (1983) "An Analysis of the Principal-Agent Problem," Econometrica, 51, 7-45.

[18] Heyman, Frederik (2002) "Pay Inequality and Firm Performance Evidence from Matched Employer-Employee Data", The Trade Union Institute for Economic Research, Working Paper 186.

[19] Holmstrom, B. (1979) "Moral Hazard and Observability", The Bell Journal of Economics, 10, 74-91.

[20] Jensen, M. and K. J. Murphy (1990) "Performance Pay and Top-Management Incentives", Journal of Political Economy, 2, 225-64.

[21] Ehrenberg, Ronald G., and Michael L. Bognanno (1990) "Do Tournaments Have Incentives Effects?", Journal of Political Economy, 98, 1307-24. 
[22] Eriksson Tor (1999) "Executive Compensation and Tournament Theory: Empirical Tests on Danish Data", Journal of Labor Economics, 2, 262-280.

[23] Knoeber, Charles R., and Walter N. Thurman (1994) "Testing the Theory of Tournaments: An Empirical Analysis of Broiler Production", Journal of Labor Economics, $12,155-79$.

[24] Lallemand, Tierry, Robert Plasman and Francois Ryck (2003) "Intra-firm Wage Dispersion and Firm Performance: Evidence from Linked Employer-employee Data", DULBEA, Working Paper.

[25] Lambert, R., D. Lacker and K. Weigelt (1993) "The Structure of Organizational Incentives, Administrative Science Quarterly, 38, 438-461

[26] Lazear, Edward.P. (1998) "Personnel Economics", MIT Press Cambridge, Third edition.

[27] Lazear Edward P. (1989) "Pay Equality and Industrial Politics", Journal of Political Economy, 97, 561-580.

[28] Lazear, Edward P., and Rosen Sherwin (1981) "Rank-Order Tournaments as Optimum Labor Contracts", Journal of Political Economy, 89, 841-64.

[29] Leonard, Jonathan (1990) "Executive Pay and Firm Performance", Industrial and Labor Relations Review, 43, 13-49.

[30] Main, Brian, Charles O’Reilly and James Wade (1993) "Top Executive Pay: Tournament or Teamwork?", Journal of Labor Economics, 4, 606-628.

[31] Moldovanu, Benny, and Sela, Aner (2001) "The Optimal Allocation of Prizes in Contests", American Economic Review, 91, 542-58.

[32] Moulton, B. (1990), "An Illustration of a Pitfall in Estimating the Effect of Aggregate Variables on Micro Units", Review of Economics and Statistics, 72, 334-338. 
[33] Munich Daniel., Jan Svejnar and K. Terrell (2005) "Returns to Human Capital under the Communist Wage Grid and During the Transition to a Market Economy", Review of Economics and Statistics, 100-123.

[34] Murphy, Kevin J (1999) "Executive Compensation" Handbook of Labor Economics, Vol. 3B, Elsevier Science, 2485-2563.

[35] O'Reilly, Charles III, Brian Main and Graef Crystal (1988) "CEO Compensation as Tournament and Social Comparison: A Tale of Two Theories", Administrative Science Quarterly, 33, 257-74.

[36] Ortin-Angel, Pedro and Vincente Salas-Fumas (2002) "Compensation and Span of Control in Hierarchical Organizations", Journal of Labor Economics, 20, 848-898.

[37] Prendergast, Canice (1999) "The Provision of Incentives in Firms", Journal of Economic Literature, 37, 7-63.

[38] Rosen, Sherwin (1986) "Prizes and Incentives in Elimination Tournaments.", American Economic Review, 76, 701-15.

[39] Rosen, Sherwin (1992) "Contracts and the Market for Executives", Contract Economics, Oxford: Blackwell.

[40] Shleifer, A. and R. Vishny (1997) "A Survey of Corporate Governance", Journal of Finance, 52, 737-783.

[41] Svejnar, J. (1999) "Labor Markets in the Transitional in Central and East European Economies," Handbook of Labor Economics, Elsevier Science , 2810-2857.

[42] Waldman, Michael (1984) "Job Assignment, Signalling, and Efficiency", RAND Journal of Economics, 8, 255-287.

[43] Winter-Ebmer, Rudolf and Josef Zweimuller (1999) "Intra-firm Wage Dispersion and Firm Performance", Kyklos, 52, 555-572.

[44] Wooldridge (2002), "Econometric Analysis of Cross Section and Panel Data", MIT Press 


\section{APPENDIX}

Table A1: Descriptive Statistics

\begin{tabular}{lccccc}
\hline & Wage & Age & Sec.Educ. & University & Female \\
\hline Top Managers & 471.83 & 48.62 & $17 \%$ & $73 \%$ & $7 \%$ \\
& $(310.41)$ & $(8.00)$ & & & \\
Level 7 & 254.6 & 46.05 & $33 \%$ & $63 \%$ & $18 \%$ \\
& $(86.00)$ & $(8.72)$ & & & \\
Level 6 & 198.00 & 46.86 & $33 \%$ & $63 \%$ & $18 \%$ \\
& $(72.89)$ & $(8.67)$ & & & \\
Level 5 & 171.49 & 45.66 & $46 \%$ & $48 \%$ & $24 \%$ \\
& $(54.06)$ & $(8.95)$ & & & \\
Level 4 & 148.55 & 45.62 & $53 \%$ & $23 \%$ & $42 \%$ \\
& $(56.21)$ & $(9.12)$ & & & \\
Level 3 & 119.50 & 43.87 & $61 \%$ & $20 \%$ & $41 \%$ \\
& $(37.86)$ & $(9.79)$ & & & \\
Level 2 & 95.44 & 43.03 & $52 \%$ & $6 \%$ & $70 \%$ \\
& $(33.66)$ & $(9.82)$ & & & \\
Level 1 & 87.69 & 36.96 & $65 \%$ & $4 \%$ & $76 \%$ \\
& $(14.70)$ & $(11.75)$ & & & \\
All Sample & 220.05 & 45.09 & $42 \%$ & $53 \%$ & $23 \%$ \\
& $(163.19)$ & $(9.53)$ & & & \\
\hline
\end{tabular}

Notes: Average wage is expressed in Czech Crowns (2001 value). Age is expressed in years. The category omitted in education is apprenticeship. 
Table A2: Regression Results ${ }^{a}$

(Clustered standard errors in parentheses)

\begin{tabular}{|c|c|c|c|c|}
\hline & $\begin{array}{c}\text { OLS } \\
(1) \\
\end{array}$ & $\begin{array}{c}\text { OLS }^{b} \\
(2)\end{array}$ & $\begin{array}{c}\text { OLS }^{c} \\
(3)\end{array}$ & $\begin{array}{l}\text { Firm Fixed Effect } \\
(4)\end{array}$ \\
\hline \multirow[t]{2}{*}{ Top Managers } & $1.16^{* * *}$ & $1.27^{* * *}$ & $1.64^{* * *}$ & $1.30^{* * *}$ \\
\hline & $(0.05)$ & $(0.06)$ & $(0.09)$ & $(0.02)$ \\
\hline \multirow[t]{2}{*}{ Level 7} & $0.65^{* * *}$ & $0.71^{* * *}$ & $0.98^{* * *}$ & $0.76^{* * *}$ \\
\hline & $(0.05)$ & $(0.05)$ & $(0.07)$ & $(0.02)$ \\
\hline \multirow[t]{2}{*}{ Level 6} & $0.45^{* * *}$ & $0.57^{* * *}$ & $0.72^{* * *}$ & $0.53^{* * *}$ \\
\hline & $(0.05)$ & $(0.06)$ & $(0.07)$ & $(0.02)$ \\
\hline \multirow[t]{2}{*}{ Level 5} & $0.39^{* * *}$ & $0.42^{* * *}$ & $0.68^{* * *}$ & $0.45^{* * *}$ \\
\hline & $(0.05)$ & $(0.07)$ & $(0.06)$ & $(0.02)$ \\
\hline \multirow[t]{2}{*}{ Level 4} & $0.31^{* * *}$ & $0.31^{* * *}$ & $0.53^{* * *}$ & $0.33^{* * *}$ \\
\hline & $(0.04)$ & $(0.09)$ & $(0.05)$ & $(0.02)$ \\
\hline \multirow[t]{2}{*}{ Level 3} & $0.15^{* * *}$ & $0.15^{* *}$ & $0.32^{* * *}$ & $0.23^{* * *}$ \\
\hline & $(0.05)$ & $(0.07)$ & $(0.06)$ & $(0.02)$ \\
\hline \multirow[t]{2}{*}{ Level 2} & $0.12^{* * *}$ & -0.03 & $0.24^{* * *}$ & $0.16^{* * *}$ \\
\hline & $(0.04)$ & $(0.11)$ & $(0.03)$ & $(0.02)$ \\
\hline \multirow[t]{2}{*}{ Private } & $-0.24^{* * *}$ & $-0.27^{* * *}$ & $-0.22^{* *}$ & \\
\hline & $(0.06)$ & $(0.08)$ & $(0.11)$ & \\
\hline \multirow[t]{2}{*}{ State } & $-0.10^{*}$ & -0.09 & -0.08 & \\
\hline & $(0.06)$ & $(0.12)$ & $(0.11)$ & \\
\hline \multirow[t]{2}{*}{ Mixed } & -0.05 & -0.21 & $0.03^{* *}$ & \\
\hline & $(0.07)$ & $(0.09)$ & $(0.11)$ & \\
\hline \multirow[t]{2}{*}{ Cooperative } & $-0.60^{* * *}$ & $-0.62^{* * *}$ & $-0.75^{* *}$ & \\
\hline & $(0.08)$ & $(0.11)$ & $(0.12)$ & \\
\hline \multirow[t]{2}{*}{ Middle Size ${ }^{d}$} & $-0.11^{* * *}$ & $-0.14^{* * *}$ & -0.15 & $-0.43^{*}$ \\
\hline & $(0.04)$ & $(0.05)$ & $(0.1)$ & $(0.24)$ \\
\hline $\operatorname{Adj} . R^{2}$ & 0.59 & 0.34 & 0.61 & 0.48 \\
\hline $\mathrm{N}$ & 8905 & 2695 & 6157 & 8905 \\
\hline \multicolumn{5}{|c|}{$\begin{array}{l}\text { Notes: }{ }^{a} \text { Coefficients for gender, age and education are not re- } \\
\text { ported; }{ }^{b} \text { The specification includes } 260 \text { firms with a total number } \\
\text { of managers smaller than } 26 .{ }^{c} \text { The regression considers firms with } \\
\text { more than } 26 \text { managers. }{ }^{d} \text { Middle Size firms are firms with } 250-500 \\
\text { employees. Omitted category: firms with more than } 500 \text { employ- } \\
\text { ees. }{ }^{*} p<0.10 ;{ }^{* *} p<0.05 ;{ }^{* * *} p<0.01 \text {; }\end{array}$} \\
\hline
\end{tabular}


Individual researchers, as well as the on-line and printed versions of the CERGE-EI Working Papers (including their dissemination) were supported from the following institutional grants:

- Economic Aspects of EU and EMU Entry [Ekonomické aspekty vstupu do Evropské unie a Evropské měnové unie], No. AVOZ70850503, (2005-2010);

- Economic Impact of European Integration on the Czech Republic [Ekonomické dopady evropské integrace na ČR], No. MSM0021620846, (2005-2011);

Specific research support and/or other grants the researchers/publications benefited from are acknowledged at the beginning of the Paper.

(c) Teodora Paligorova, 2005

All rights reserved. No part of this publication may be reproduced, stored in a retrieval system or transmitted in any form or by any means, electronic, mechanical or photocopying, recording, or otherwise without the prior permission of the publisher.

Published by

Charles University in Prague, Center for Economic Research and Graduate Education (CERGE) and

Economics Institute (EI), Academy of Sciences of the Czech Republic

CERGE-El, Politických vězñu 7, 11121 Prague 1, tel.: +420 224005 153, Czech Republic.

Printed by CERGE-EI, Prague

Subscription: CERGE-El homepage: http://www.cerge-ei.cz

Editors: Directors of CERGE and EI

Managing editors: Deputy Directors for Research of CERGE and EI

ISSN 1211-3298

ISBN 80-7343-054-1 (Univerzita Karlova v Praze, CERGE)

ISBN 80-7344-043-1 (Národohospodářský ústav AV ČR, Praha) 
CERGE-EI

P.O.BOX 882

Politických vězňů 7

11121 Praha 1

Czech Republic http://www.cerge-ei.cz 